\author{
CUNegeo \\ International Journal of Environment and Geoinformatics (IJEGEO) is an international, \\ multidisciplinary, peer reviewed, open access journal.

\section{Assessment of Water Level in Dadin Kowa Dam Reservoir in Gombe State Nigeria Using Geospatial Techniques}

\section{Ezeikel Elisha JESSE, J.I. IGBOKWE, Etido ESSIEN \& Yakubu Lawi SUMI}

\section{Chief in Editor} \\ Prof. Dr. Cem Gazioğlu

\section{Co-Editor} \\ Prof. Dr. Dursun Zafer Şeker, Prof. Dr. Şinasi Kaya, \\ Prof. Dr. Ayşegül Tanık and Assist. Prof. Dr. Volkan Demir
}

Editorial Committee (2019)

Assos. Prof. Dr. Abdullah Aksu (TR), Prof. Dr. Bedri Alpar (TR), Prof. Dr. Lale Balas (TR), Prof. Dr. Levent Bat (TR), Prof. Dr. Paul Bates (UK), Prof. Dr. Bülent Bayram (TR), Prof. Dr. Luis M. Botana (ES), Prof. Dr. Nuray Çağlar (TR), Prof. Dr. Sukanta Dash (IN), Dr. Soofia T. Elias (UK), Prof. Dr. A. Evren Erginal (TR), Assoc. Prof. Dr. Cüneyt Erenoğlu (TR), Dr. Dieter Fritsch (DE), Assos. Prof. Dr. Çiğdem Göksel (TR), Prof.Dr. Lena Halounova (CZ), Dr. Hakan Kaya (TR), Assoc. Prof. Dr. Maged Marghany (MY), Prof. Dr. Michael Meadows (ZA), Prof. Dr. Nebiye Musaoğlu (TR), Prof. Dr. Erhan Mutlu (TR), Prof. Dr. Masafumi Nakagawa (JP), Prof. Dr. Hasan Özdemir (TR), Prof.Dr. Chryssy Potsiou (GR), Prof. Dr. Erol Sarı (TR), Prof. Dr. Maria Paradiso (IT), Prof. Dr. Petros Patias (GR), Prof. Dr. Elif Sertel (TR), Prof. Dr. Nüket Sivri (TR), Assoc. Prof. Dr. Füsun Balık Şanlı (TR), Prof. Dr. Uğur Şanlı (TR), Assoc. Prof. Dr. Oral Yağcı (US), Prof. Dr. Seyfettin Taş (TR), Assoc. Prof. Dr. Ömer Suat Taşkın (TR), Dr. İnese Varna (LV), Dr. Petra Visser (NL), Prof. Dr. Selma Ünlü (TR), Assoc. Prof. Dr. İ. Noyan Yılmaz (AU), Prof. Dr. Murat Yakar (TR), Assit. Prof. Dr. Sibel Zeki (TR) 


\title{
Assessment of Water Level in Dadin Kowa Dam Reservoir in Gombe State Nigeria Using Geospatial Techniques
}

\author{
Ezeikel Elisha Jesse ${ }^{1}$, J.I. Igbokwe ${ }^{2}$, Etido Essien ${ }^{3, *}$ iD, Yakubu Lawi Sumi ${ }^{1}$ \\ ${ }^{1}$ Department of Surveying and Geoinformatic, Abubakar Tafawa Balewa University Bauchi State, Nigeria \\ ${ }^{2}$ Department of Surveying and Geoinformatic, Nnamdi Azikiwe University Awka Anambra State, Nigeria \\ ${ }^{3}$ Climatology Research Group, Department of Environmental Geography University of Bayreuth, Germany
}

Received 26 Nov 2018 Accepted 08 Apr 2019

* Corresponding Author

Using Geospatial

How to cite: Jesse., et al., (2019). Assessment of Water Level in Dadin Kowa Dam Reservoir in Gombe State Nigeria Using

\begin{abstract}
Reservoirs have been found to provide a convenient source of water for different purposes to rural communities and this makes them indispensable, and they are quite important in improvement of livelihoods of rural community. The study applied Geospatial techniques in assessing the Dadin Kowa Dam Water level in Gombe State, Nigeria. To achieve the objectives of this study, two major data were acquired. The water reservoir level recorded from 1987 till 2013 was collected from Upper Benue River Basin Development Authority also LANDSAT satellite imagery from 1987, 2000 and 2015 were acquired. Supervised image based classification was applied to assess the class of land use land cover in the area of study. The extents (surface areas) of the Dadin Kowa Dam were delineated from LANDSAT satellite images using the Normalized Difference Water Index (NDWI). the water level record was arranged in Microsoft Excel and the mean of the water level for 1987, 2000, and 2015 were used to assess the change both in extent and volume. The result shows that from 1987 to 2000 the water level increased and decreased from 2000 to 2015 due to the climate change condition and the high rate consummation of water due to population growth of the area from 266844 in 1991 to 367500 in 2016. Dadin Kowa reservoir may completely dry up by the year 2029 if the climatic condition remains as it is.
\end{abstract}

Keywords: Dam Management, Water level, LANDSAT, NDW, Landcover/Landuse

\section{Introduction}

Land use land cover change has significant effect on hydro-logical processes at the watershed level. (Chen et al, 2009; Balcik \& Göksel, 2012) Forecasting the spatial distribution of water availability requires hydrologic modelling of groundwater and surface water (Wijesekara et al, 2012; Burak et al; 2002; Gazioğlu et al; 1998) over a range of temporal and spatial scales.

Mapping vegetation of land cover on a yearly basis at global scales using remotely sensed data has a vast history of application (Cihlar et al, 2005; Osgouei. \& Kaya, 2017).). This is because changes in landcover can affect runoff direction and flow patterns through the addition of interception, infiltration, overland flow and evaporation processes (Hundecha et al; 2004; Vivoni, 2007; Kaya et al; 2014). The nature and value of the earth life support system have been illuminated primarily through their disruption and loss (Daily, 1997; Göksel, 1998).

Water supply issues is creating unprecedented pressures in developing country because of increasing population and economic demands (Bauep et, al 2014). Therefore, Global data processing of satellites image provides temporal and spatial time series of lakes surface height with a decimetre precision on the whole earth (Cretaux et al, 2011).

Surface water is important for life, yet we have surprisingly poor knowledge of the spatial and temporal dynamics of surface freshwater discharge and changes in storage globally (Alsdorf et al; 2007). Water resources on the continental surface square measure restricted, and therefore the abstraction and temporal distribution of this resource doesn't forever meet the foremost crucial desires (Calmant et al 2008; Frappart et al 2006; Kaya et al; 2004). However, the water volume of water stored in a lakes and reservoirs cannot be measured directly, traditionally the water volume in a lake or reservoir is estimated based on in-situ water levels and bathymetry maps (Duan \& Bastianssen 2013; Medina et al, 2008; Zhang et al, 2006; Göksel et al; 2004). Therefore, bathymetry maps are typically non-existent or tough to get for a given lake or reservoir (Duan \& Bastianssen 2013). Because of the use of remote sensing approach, the number of gaging stations have decreased in recent years around the world (Duan \& Bastianssen 2013; Cretaux et al, 2006). In recent decades, the event of remote sensing and geographic information system has shown us with new strategies to monitor water levels and surface areas of lakes (Zhu et al, 2014). in the past few years' numerous studies have attempted to monitor the fluctuation of Lake or reservoir using remote sensing 
techniques (Zhu et al, 2014; Yan \& Qi, 2012; Yücel et al; 2002; Wang et al, 2013; Phan et al, 2012).

Recent studies have demonstrated the potential of combining satellite imagery and radar altimetry to estimate the volume of water stored in lakes, rivers, and reservoir, and how these volumes change in response to climate variability and/or anthropogenic effects using SAR images, multispectral images, or multi-satellite observations (Bauer 2003).

Some studies also have highlighted difficulties in monitoring reservoir, lakes and discussed it to some extend like in (Birkett et al, 2011; Wang et al, 2013; Phan et al, 2012; Frappart et al. 2006). The issue about water resources can be efficiently manage by the use of remote sensing data which include microwave, infrared, radar and visible sensors. Among the mentioned remote sensing approach, microwave remote sensing provides a unique capability for mapping water bodies and delineate water boundaries over large areas of the land surface (Alsdorf et al, 2007; Calvet et al, 2011).

Often the public is kept uninformed about water levels because it is sensitive national and international information that affects the livelihoods of large groups of people. Regular information on water levels is not always disclosed to water and environmental professionals (Alsdorf et al, 2007).

The use of remote sensing data about water bodies provide reliable information for the assessment of present and future water resources, climate models, agriculture suitability, river dynamics, wetland inventory, watershed analysis, surface water survey and management, flood mapping, and environment monitoring, which are critical for proper management of water resources on the Earth (Zhu, et al, 2014; Desmet \& Govers 1996; Sun et al, 2012).

Dadin Kowa dam is the major source of water for drinking, irrigation, hydro power generation in Gombe town, Gombe State (Fig1). However, in spite of all these importance, the reservoir has a devastating effect. In 2012, about 26,000 people were displaced by this reservoir (NEMA, 2012) due to over flooding and have affected the land use activities of the area. Even though natural disasters cannot be prevented but it can be predicted with adequate information so that destruction of lives and properties can be avoided (ICLEI, 2012).

Agriculture is one of the very important sector in Nigeria economy, it provides foreign cash revenue, employment and food security (O'Hara, 2000; Abdullaev et al; 2009). Climatic conditions and insufficient internal water resources have put pressure on water reservoirs. Northeast is in fact largely an arid area where evaporation (1200-1600 mm) exceeds rainfall and annual precipitation is below $200 \mathrm{~mm}$ (UNDP, 2007). Regional stream flow is characterized by an extreme intra-annual variability and is also unevenly spatially distributed (World Bank, 2003; Kazbekov et al, 2007).

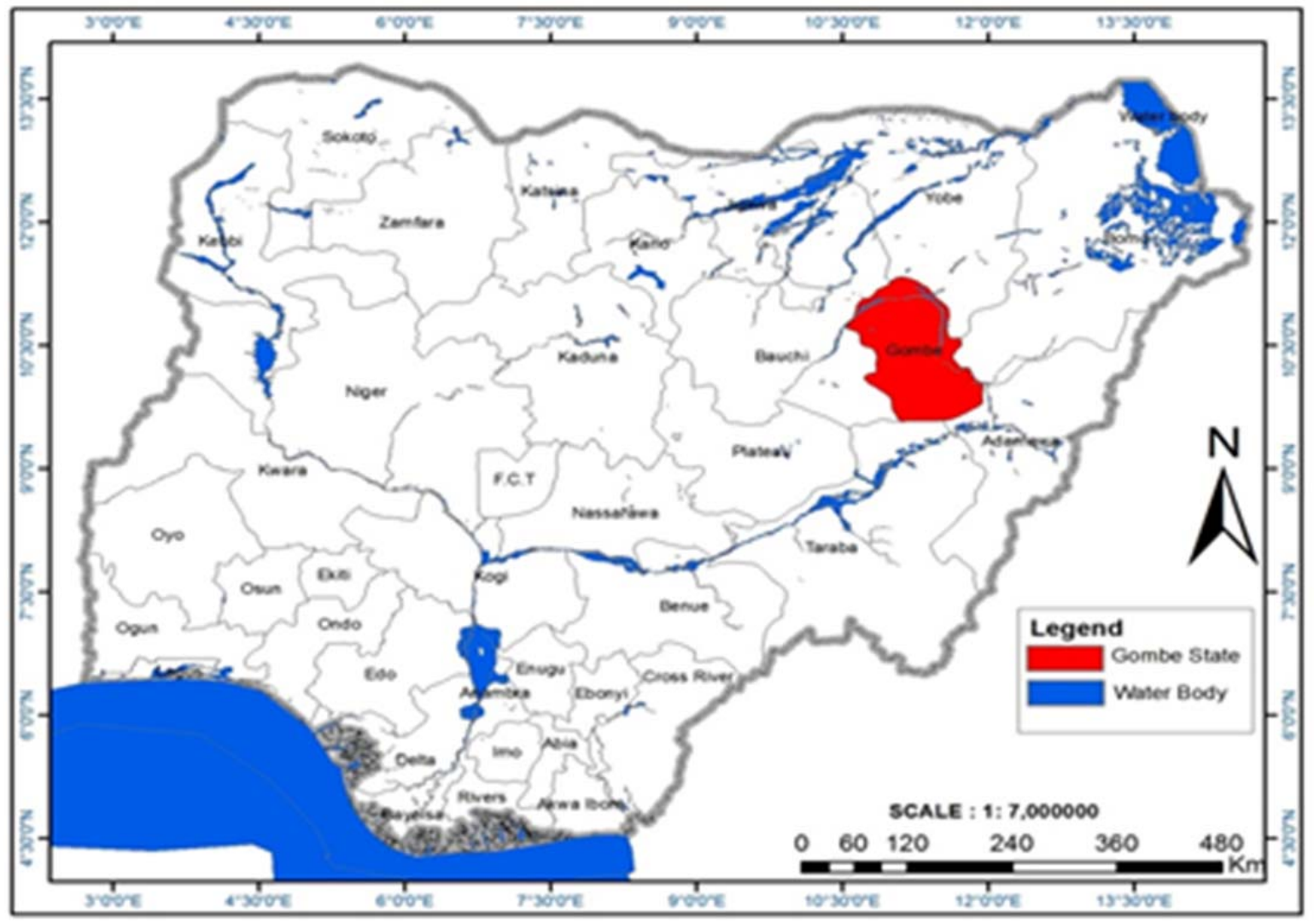

Figure 1a: Map of Nigeria with Gombe State. (Source: Ministry of Land surveying Gombe state) 




Figure 1b: location of Dadin Kowa Dam, Gombe State. State (Source: Ministry of Land surveying Gombe state)

The two main Trans Boundary Rivers in Nigeria, the Niger and River Benue, satisfy $82 \%$ of the total water demand of Nigeria, whereas only $18 \%$ of the demand is satisfied by the internal Kashka Darya, Zarafshan and Surkhan Darya rivers in the north (Heaven et al, 2002; Dukhovny, 2003; Micklin, 2004). At present approximately $90 \%$ of water resources in Nigeria are used for irrigated agriculture (UNDP 2007; Rakhmatullaev et al, 2006) and about $24 \%$ of irrigation water comes from water reservoirs, the remaining being pumped from rivers and aquifers (FAO, 2007). The total number of man-made water reservoirs in Nigeria is 55 with a total volume capacity of about $19 \mathrm{~km} 3$ and a useful volume capacity of $14.5 \mathrm{~km} 3$ (UNDP, 2007). Nowadays there are almost no attractive sites for the construction of new reservoirs in Nigeria (UNDP, 2007). Thus it is of strategic importance to rationally estimate the available water resources in existing reservoirs to ensure a guaranteed water supply to the different water users. In fact, according to the Federal Ministry of Agriculture and Water Resources (FMAWR), out of the 27 inspected reservoirs, 11 are almost completely silted up, and 5 other reservoirs the silt has almost reached the level of the outlet structures (UNDP, 2007), Increase in population means high demand of water. The drying up of this reservoir can lead to hunger, unemployment and negatively affect the state internally generated revenue (IGR).

Satellite remote sensing for the analysis of water volume variation has been used in the related literature (Tourian et al, 2015; Birkett, 1995; Frappart et al, 2005; Crétaux et al, 2006) have discussed how satellite radar altimetry can be used to derive water levels of different water bodies (Duan et al, 2013). Recently, (Baup et al 2014) combined different high-resolution satellite data and altimetry to estimate the volume changes of the lakes that are mainly used for irrigation in France (Tourian et al, 2015). Water volume changes gained from the combination of altimetry and imagery were removed from the total water storage anomaly estimated using observations from the GRACE gravimetric measurement from space mission to estimate soil water content variations (Frappart et al, 2011; Ramillien et al, 2014; Singh et al 2012). (Wang et al 2013) calculate the trend of water level change of 56 large lakes in China to answer questions such as how much water levels of major lakes in China have changed, the water volume of Lake Qinghai was also estimated using ICESat altimetry data (Zhu, et al, 2014; Jensen 2009).

The development of satellite radar/laser altimetry and satellite imagery has made it possible to monitor both water level and surface area of the lake or reservoir with remote sensing, therefore, it is possible to give the relationship between water level and surface area of a given lake based entirely on satellite data ( $\mathrm{Zhu}$, et al, 2014). However, these studies mostly focused on the detection and analysis of the surface extent and water volume in response to either climate change or human impact in the environment ( $\mathrm{Zhu}$, et al, 2014; Rokni 2014). To our knowledge, almost all of the published works on an extraction of surface lakes in cryospheric environments have used the satellite remote sensing data. (Jawak et al, 2015). (Hu et al, 2007) used the decision tree and programming method for extracting water body information from the flood affected region, (Yang and Wang 2008) developed a semi-automated change 
detection approach and used it for extracting water feature form satellite image, (Sharma et al, 2007) developed an automatic extraction method used for extracting water body from IKONOS and other high resolution satellite image (Jawak et al, 2015).

\section{Materials and Methods}

The methodological approach of this study is summarized in the flowchart below (Figure 2)

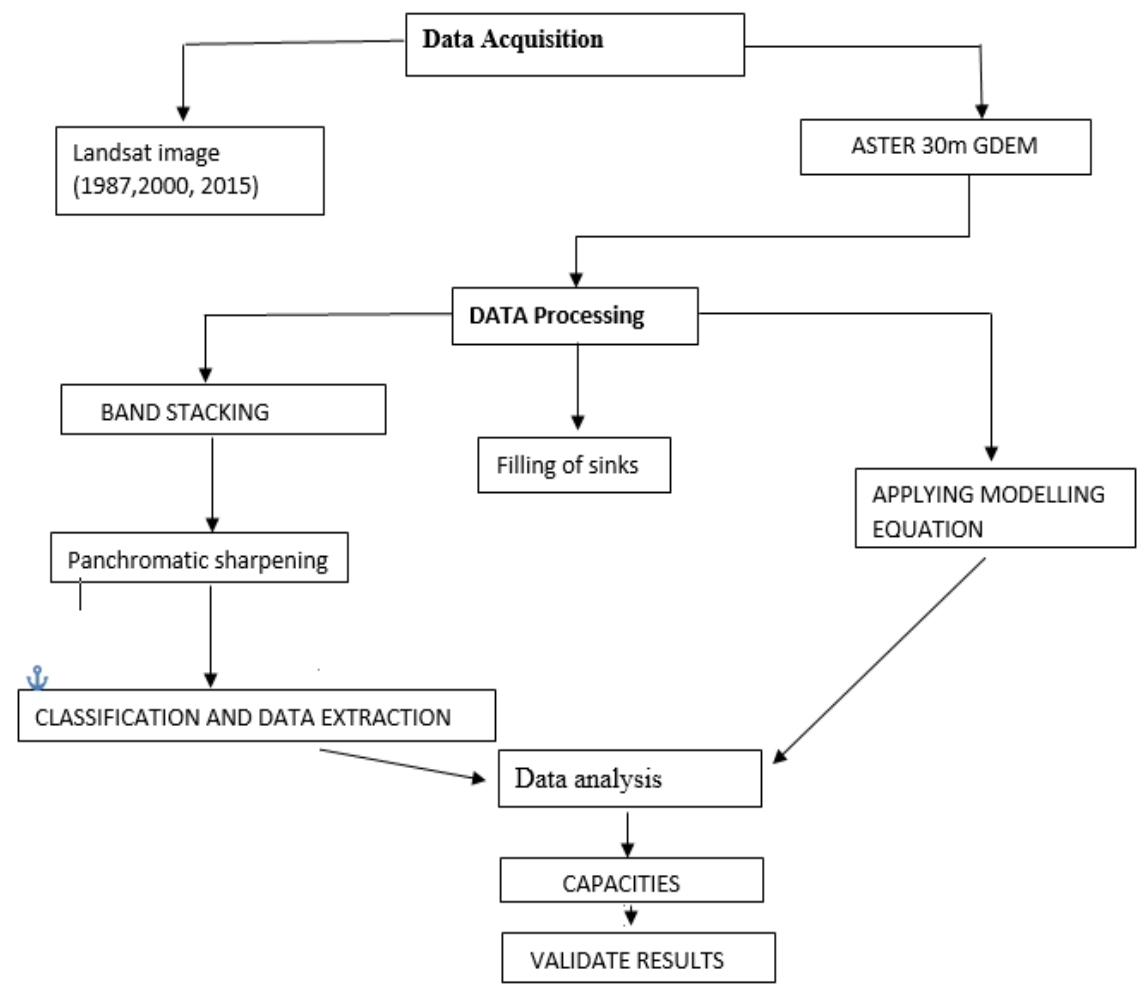

Figure 2. Methodology of study

\section{Study Area}

The study was carried out in Dadin Kowa Dam connecting Gongola River Located in Gombe State, Nigeria (Figure 1b). The area lies between latitudes $10^{\circ}$ $19^{\prime} \mathrm{N}$ and latitude $10^{\circ} 32^{\prime} \mathrm{N}$, and longitudes $11^{\circ} 48^{\prime} \mathrm{E}$ and longitude $11^{\circ} 54^{\prime}$ E. The dam is situated about 35kilometers to the east of Gombe town, and provides drinking water for the town. The dam was built by the federal government in 1984, with the aiml of providing irrigation and electricity for the planned Gongola sugar plantation project (Timawus, 2010). The reservoir has capacity of 800 million cubic meters of water and a surface area of 300 square kilometres and has potential as a source of fish (Timawus, 2010). The state has an area of 20,265 kilometres square and a population of around 2,356,000 people (NPC 2006).

\section{Data}

LANDSAT images for year 1987, 2000 and 2015 and Digital Elevation Model (DEM) Dataset for the study area were used. The LANDSAT images were obtained from the US Geological Survey (USGS) Global Visualization.

\section{Image Pre-Processing}

LANDSAT image TM/ETM/OLI of the study area from 1987, 2000, and 2015 were used in this study and the image with cloud cover less than $20 \%$ were considered for this study. LANDSAT TM band for water identification is band 5 because of its ability to discriminate vegetation and soil moisture levels. LANDSAT TM bands 3, 4, and 5 is normally the best combination of bands for wetland detection (Calmant et al 2008). The sub-images containing the Dam were extracted using ERDAS software. The image was geometrically corrected then projected in geographical coordinate system WGS84 datum.

\section{Image Classification}

Supervised image classification using the maximum likelihood algorithm in Erdas Imagine software was used to generate three main land use land cover classes for all images.

(1) Farm land dominated by human activities like agriculture area, plantation area, bush burned, and bush cleared for road construction.

(2) Forest area: area dominated by thick vegetation covered and

(3) Water body: area cover by rivers, streams and its ramifications.

These land use land cover classes were derived from images 1987, 2000, and 2015 for the study areas. This was due to the fact that the field work, whereby the spectral characteristics of the classes in the sampled area have been identified.

\section{Transformation Equation}

Transformation approach was use to minimise the concentration of water into the river channel. The hydrograph developed in 1938 by (Snyder, 1938; 
USACE, 2008) was used to calculate runoff coefficient and catchment lag.

$\mathrm{Qp}=0.28 \mathrm{CIA}$

Where;

$$
\begin{aligned}
& \mathrm{QP}=\text { Peak discharge }(\mathrm{m} 3 / \mathrm{s}) \\
& \mathrm{C}=\text { Runoff coefficient } \\
& \mathrm{I}=\text { Rainfall intensity }(\mathrm{mm} / \mathrm{h}) \\
& \mathrm{A}=\text { Catchment area }(\mathrm{km} 2) \\
& 0.28=\text { Conversion factor }
\end{aligned}
$$

Catchment time lag The catchment lag time tp was calculated using Eq.4:

$\mathrm{Tp}=\operatorname{CCt}(\operatorname{LLc}) 0.3$

Where;

$\mathrm{Tp}=$ Basin lag time $(\mathrm{h})$

$\mathrm{C}=$ Conversation constant of 0.75

$\mathrm{Ct}=$ Runoff coefficient from gauged catchment

$\mathrm{L}=$ Longest channel from outlet $(\mathrm{km})$

$\mathrm{Lc}=$ Length of the main stream from the outlet to the catchment centroid $(\mathrm{km})$

L and Lc were calculated from the DEM hydroprocessing procedure.

\section{Land cover Change Detection}

Before image classification, a classification scheme must be established. (Yang 2002). Changes in landcover between 1987 and 2013 were determined using a supervised classification method based on a combination of LANDSAT TM bands 1-5 and 7 (maximum likelihood approach) with the information generated from field observation. Following the supervised classification of imagery, Post-classification refinements were applied to reduce classification errors caused by the similarities in spectral responses of certain classes according to (Yuan et al. 2005). This post-classification approach provides statistical proof on how landcover has changed and was used to calculate the landcover change map over time. The accuracy of the landcover classification was assessed using a confusion matrix to compare the 2015 classification results to the ground observations. For each landcover class, a confusion matrix was generated to access the overall accuracy, the Kappa statistic, and the producer and user accuracy for each class were calculated (Congalton \& Green 2009).

\section{Altimetry Water Level Datasets}

Altimetry water levels of Dadin Kowa Reservoir were collected from Upper Benue River Basin Development Authority databases. These databases were chosen because of the temporal resolution, level of processing and data availability for the period of study. The altimetry data was recorded every day of month from 1987 till 2013, because of lack of coordinate, the data cannot be plotted in GIS environment, the overall average water level was calculated from the monthly water level average for the year of 1987, 2001, and 2013 in Microsoft excel, and was used as water depth in calculation of volume of water.

\section{Delineation of Reservoir Surface Area}

The extents (surface areas) of the Dadin Kowa Dam was delineated from LANDSAT satellite images using the Normalized Difference Water Index (NDWI) by (McFeeters, 1996) as given by this Equation;

$\mathrm{NDWI}=\frac{\text { GREEN-NIR }}{\text { GREEN }+\mathrm{NIR}}$

Where, GREEN and NIR are the respective bands. Water has positive values due to their higher reflectance of the green band compared to the NIR band, vegetation and soil have zero or negative values because of their high reflectance of the NIR band compared to the green band.

The Modified Normalized Difference Water Index (MNDWI), which replaces the NIR band in Equation (1) with the mid-infrared red (MIR) band, has been reported to perform better than NDWI However, we found that the MIR band (Band 5) for both study areas had low spectral reflectance, the boundaries of the image scenes drift when the MNDWI was applied. Therefore, used NDWI to delineate the reservoir surface areas in this research, Band 2 of LANDSAT image and Band 4 were used in the Equation (3). With the aid of visual inspection and NDWI, the raster calculator tool in ArcGIS was used for computation of the NDWI equation. Ranging from 0.01 to 1 , water bodies of both study areas were extracted. The final range was based on the observation of detecting water bodies within a trial and error range from 0 to a positive value.

\section{Results}

\section{Delineation of the Catchment area of Dadin Kowa Reservoir Basin.}

The figure 3 below shows the catchment area of Dadin Kowa dam, the total area of the catchment delineation is about $4,751 \mathrm{~km} 2$. Different stream or water body within the area drained into the Dam trough the watershed. the amount of water reaching the reservoir depend on the size of area, the amount of precipitation and the loss through evaporation.

\section{Changes in Landcover}

The results has shown that farmland keep increasing in the study area while forest land keep decreasing since 1987 to 2015 because population growth has made a lot of people go into farming, which is the major source of income in Dadin Kowa people, (table 2) shows the overall statistic of land use in Dadin Kowa and confusion matrix of landcover types using field observations showed that the accuracy of landcover change analysis was $97 \%$ with a Kappa statistic of 0.878 (Table 1). User's accuracies ranged from $98 \%$ for water bodies to $87 \%$ for forest and $97 \%$ for farmland 


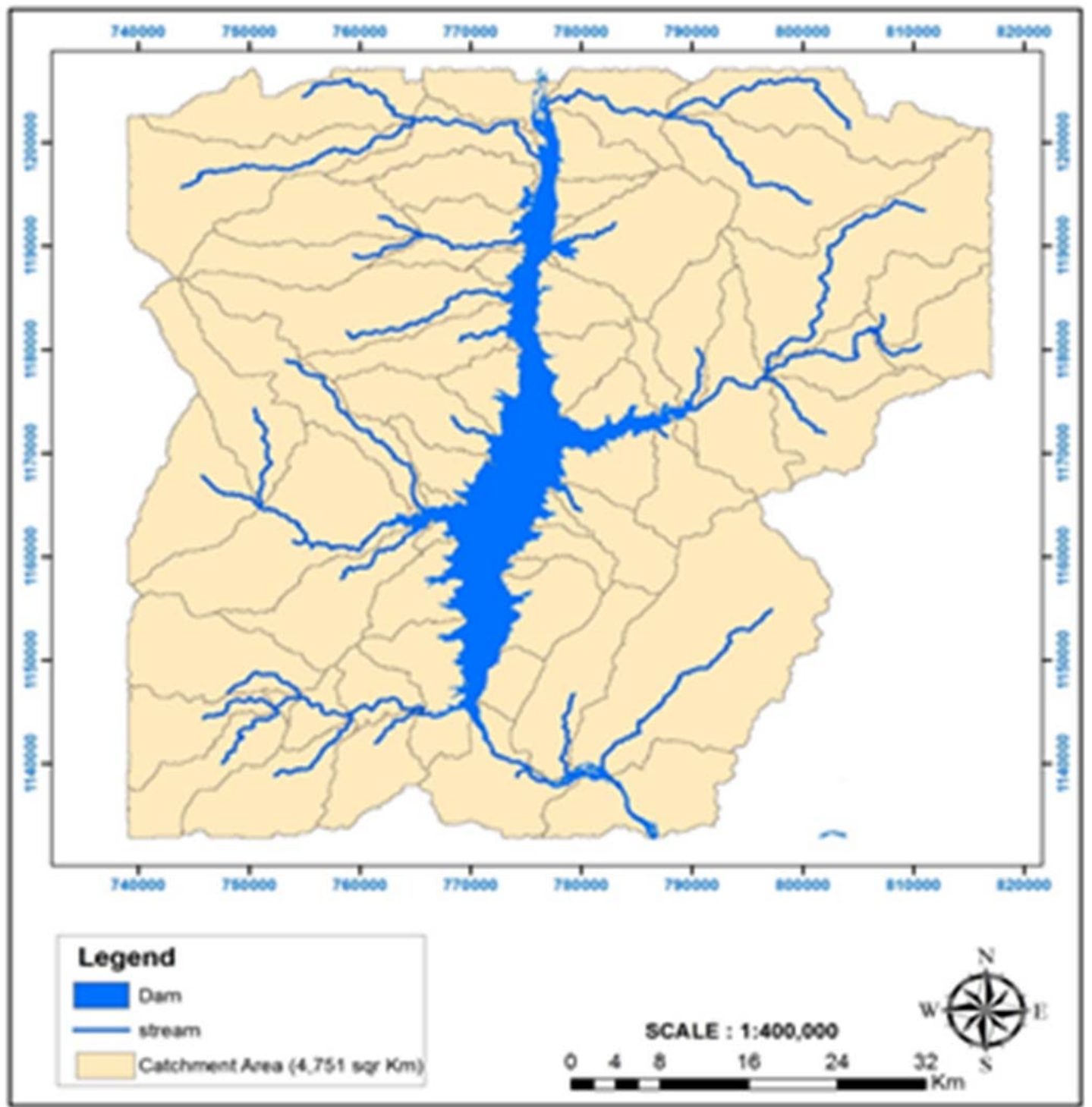

Figure 3: Delineation of Dadin Kowa dam catchment area.

\section{Estimation of the storage Capacity change in Dadin Kowa Dam.}

The general estimate of the volume of water in this study was done using GIS procedure which is based on the simple relationship based on depth, width and throwback. Instead of measuring all the parameters, GIS procedure makes use of the coordinates and the reduced levels to calculate the storage volumes in a manner that represent a basin being emptied over time. The allow evaluation of storage changes in water levels over time to be estimated. The figure (6) shows the spatial and temporal change of Dadin Kowa Dam over the 28 years. The table (3) shows that, in 1987 the total area of the Dam was $38858400 \mathrm{Km} 2$ and the volume of water was estimated as $9326404584 \mathrm{~m} 3$. In 2000 the volume increased to $69764814900 \mathrm{~m} 3$ with total area of $287370000 \mathrm{~m} 2$ due to the high amount of rainfall experience in year 2000. The volume reduced dramatically in 2015 to $38292230358 \mathrm{~m} 3$ with total area of $159378300 \mathrm{~m} 2$. Due to the high rate of population demanding for water as basic need.

Table 1: Confusion matrix for validation of the classified

\begin{tabular}{|l|l|l|l|l|}
\hline & $\begin{array}{l}\text { Water } \\
\text { bodies }\end{array}$ & Farm & Forest & UA \\
land & $(\%)$
\end{tabular}


Table 2: Land use/Cover table of Dadin Kowa Dam Catchment area 2015

\begin{tabular}{|l|l|l|l|l|}
\hline Value & Class Names (2015) & Count & Area $\left.\mathbf{( k m}^{\mathbf{2}}\right)$ & Pct (\%) \\
\hline 1 & Water Body & 177087 & 159.39 & 2.75 \\
\hline 2 & Farm Land & 2149329 & 1934.40 & 33.39 \\
\hline 3 & Forest & 4111059 & 3699.95 & 63.86 \\
\hline Total & & $\mathbf{6 4 3 7 4 7 5}$ & $\mathbf{5 7 9 3 . 7 2 7 5}$ & 100 \\
\hline
\end{tabular}

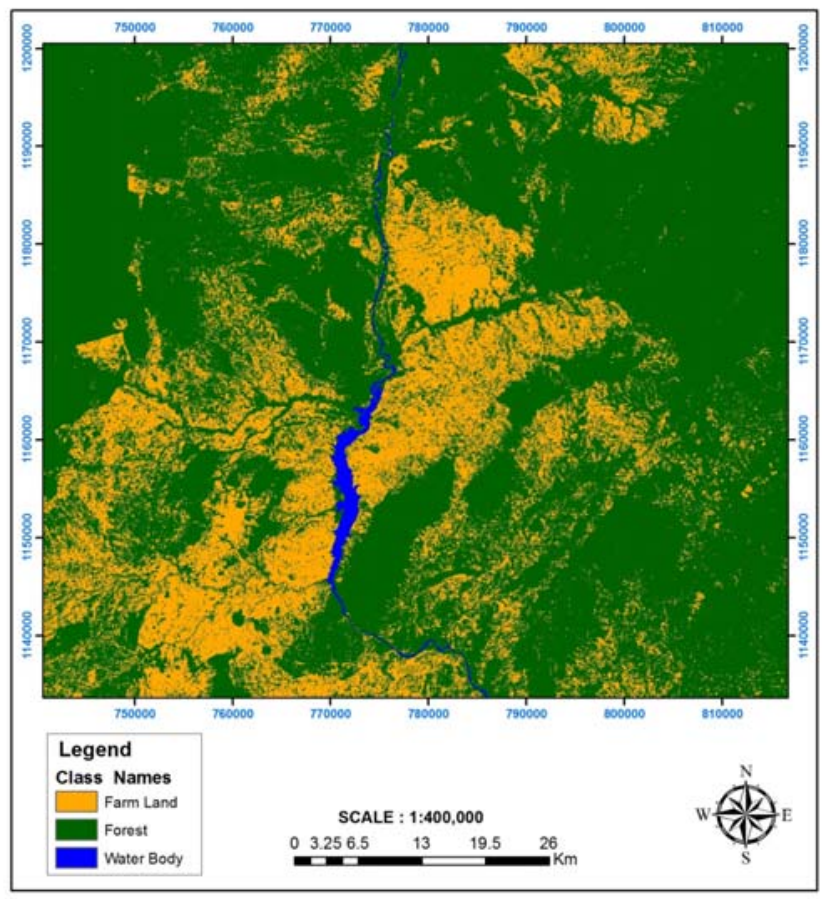

1987

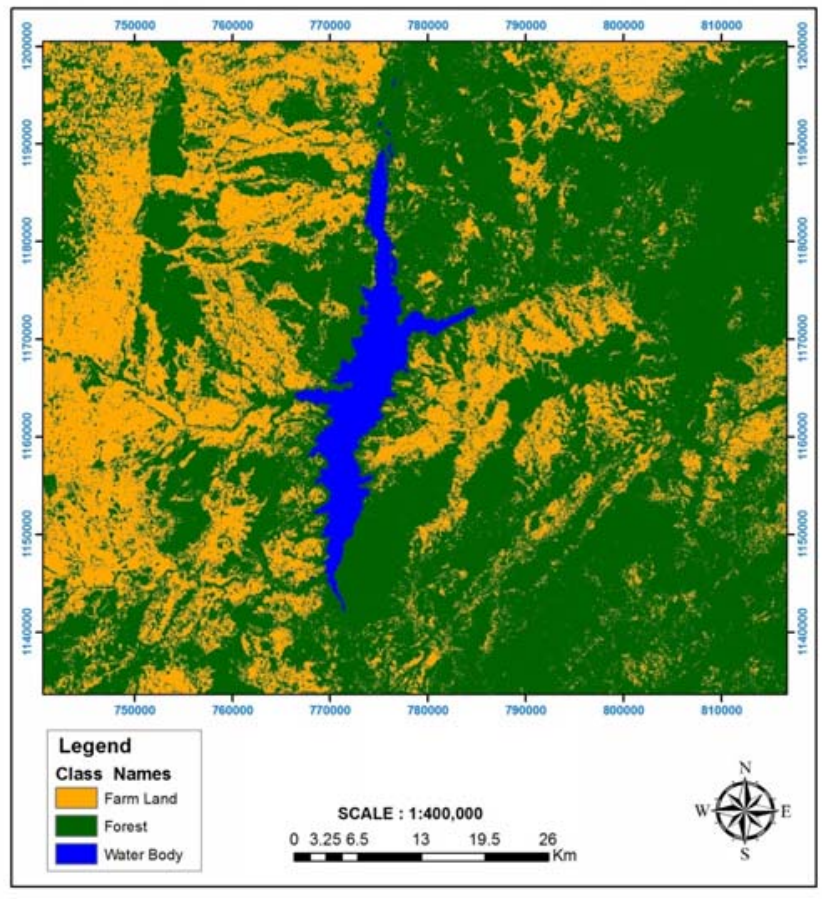

2015

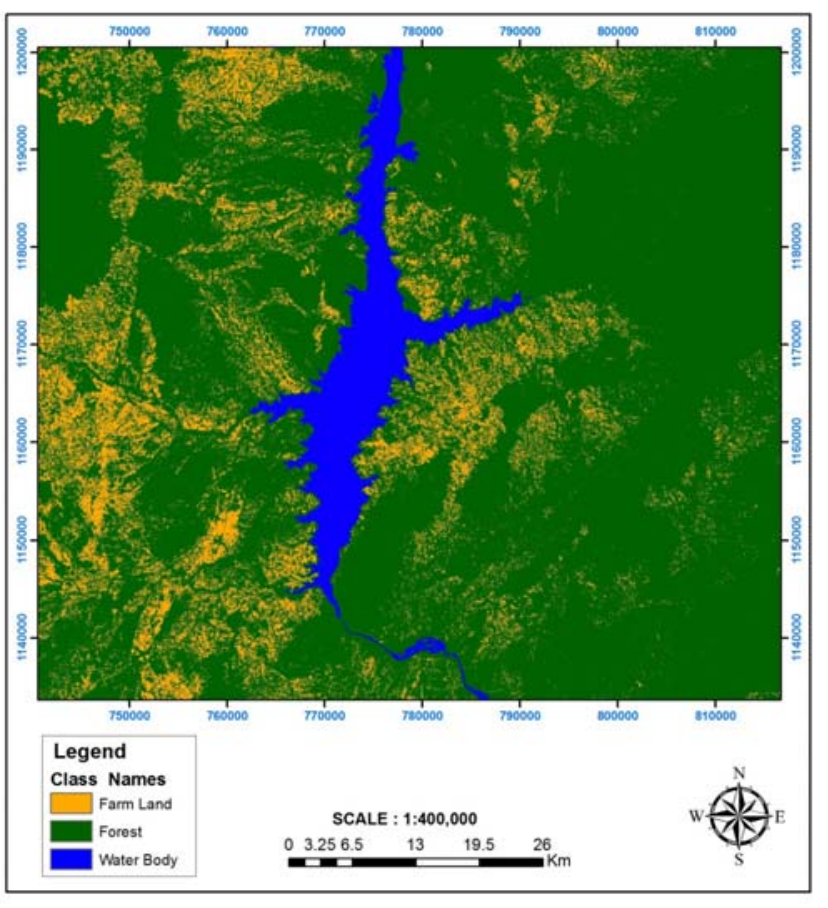

2000

Figure 4: Changes in Land use/Cover map of Dadin Kowa Dam catchment area a. 1987 b. 2000 c. 2015 


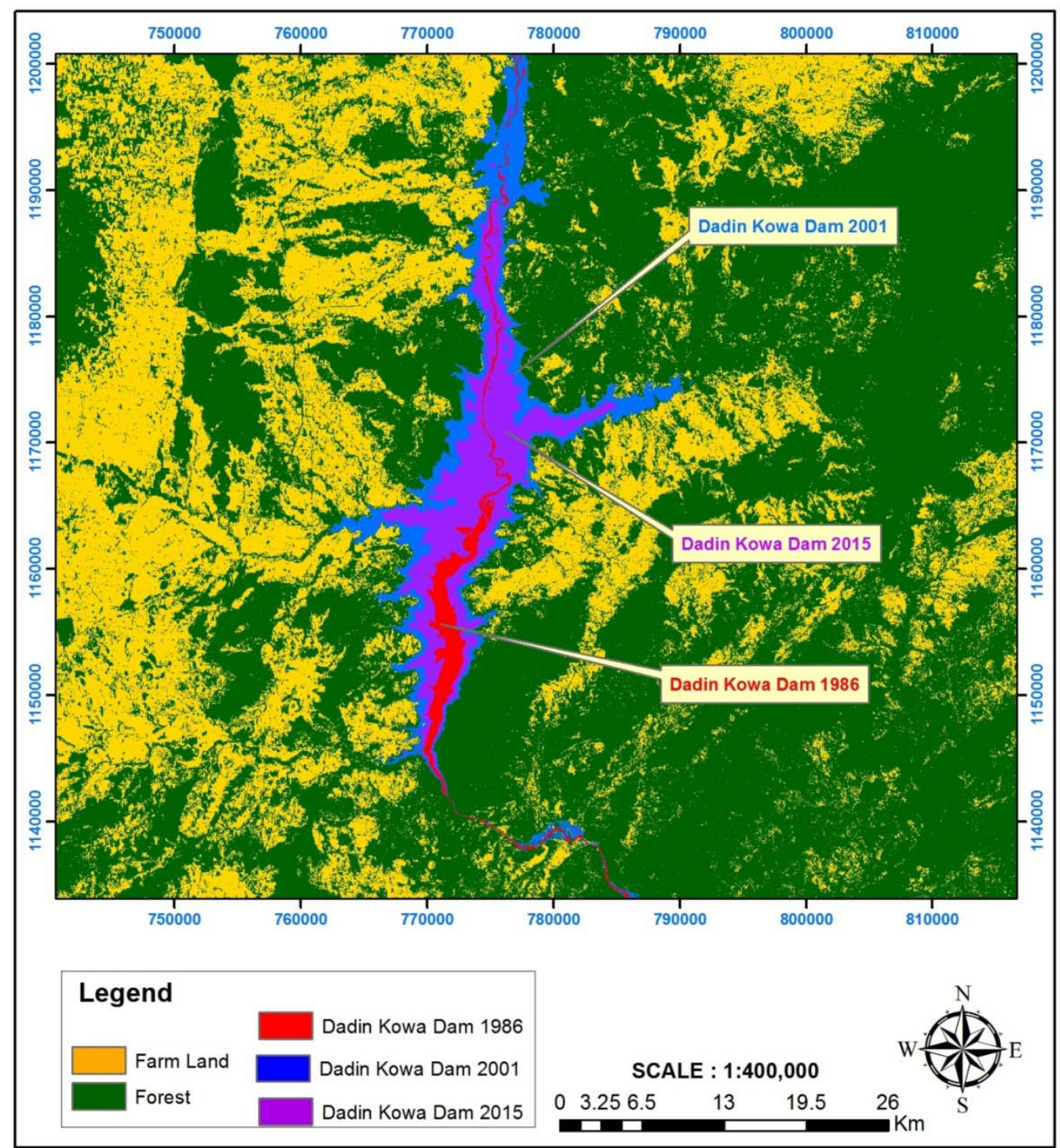

Figure 5. Changes in land use/ cover of Dadin Kowa

Tabel 3: Volume of water in Dadin Kowa dam

\begin{tabular}{|l|l|l|l|l|l|}
\hline Value & $\begin{array}{l}\text { Dadin Kowa } \\
\text { Dam }\end{array}$ & $\begin{array}{c}\text { Area (m2) } \\
\text { covered by } \\
\text { the river }\end{array}$ & $\begin{array}{l}\text { Average } \\
\text { Depth (km) }\end{array}$ & Volume (m3) & $\begin{array}{l}\text { Volume } \\
(\%)\end{array}$ \\
\hline 1 & October 1987 & 38858400 & 240.01 & & \\
\hline 2 & October 2000 & 287370000 & 242.77 & 69764814900.00 & 59.43 \\
\hline 3 & $\begin{array}{l}\text { December } \\
2013\end{array}$ & 159378300 & 240.26 & 38292230358.00 & 32.62 \\
\hline & Total & & & $\mathbf{1 1 7 3 8 3 4 4 9 8 4 2}$ & $\mathbf{1 0 0 . 0 0}$ \\
\hline
\end{tabular}




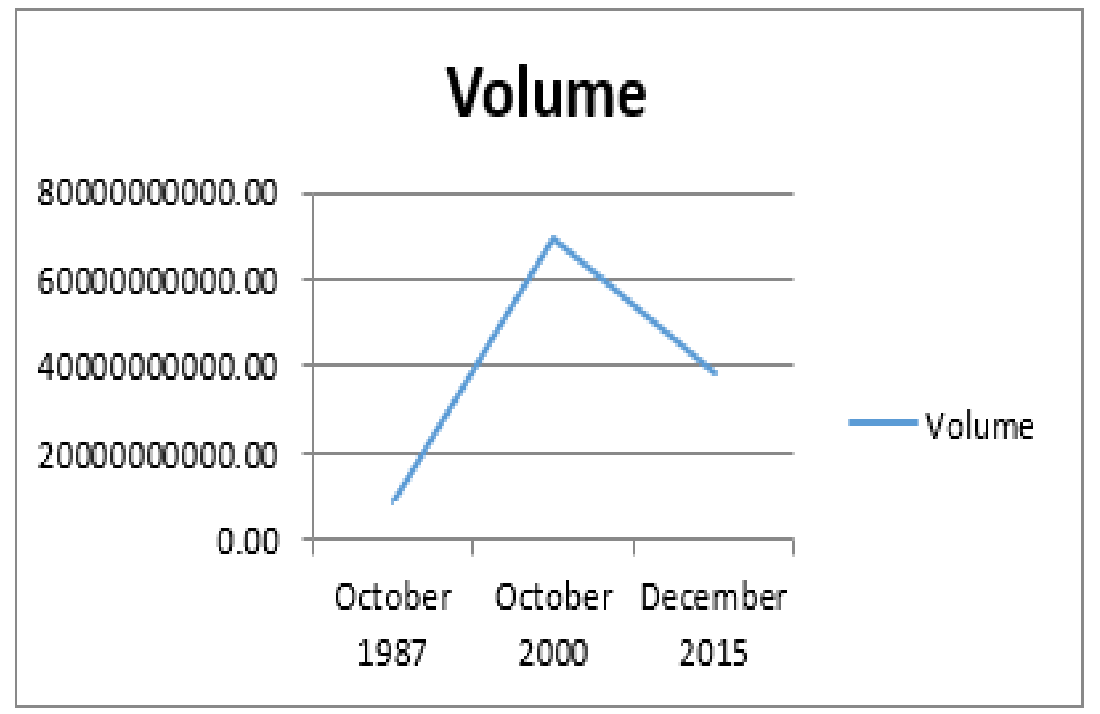

Figure 6: changes in volume of water in Dadin Kowa Dam

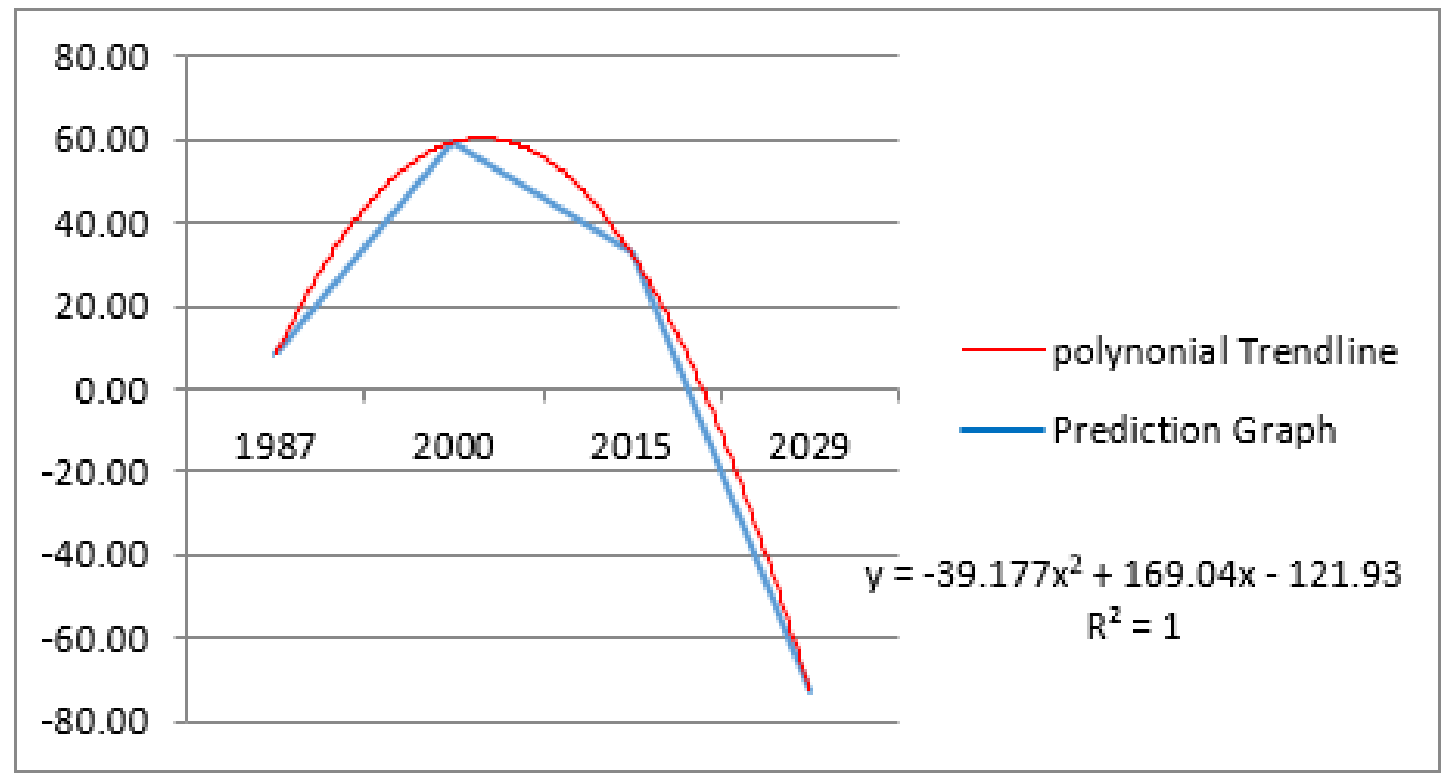

Figure 7: Polynomial trendline predicting water level in Dadin Kowa Dam with time

\section{Predicting the storage capacity of Dadin Kowa Dam} for future development and planning.

The linear forecasting trend line equations generated in the graph (Fig 7) shows the future storage capacity of the Dam. The years were not randomly chosen. They were chosen based on the years of LANDSAT data processed. The LANDSAT images of 1987, 2000 and 2015 do not have regular interval 13 and 15 years intervals respectively. 14 year was used as Average period. The storage capacity was determined for 2029 using the polynomial trend line equation generated from graph below. The polynomial trend line equation was used because it $\mathrm{R}$ Square $\mathrm{R}=1$, this give good relationship between the graph and the prediction trend line see figure (6 and 7)

Figure 6.7 shows that in 2029 the water may completely decrease $80 \%$ in negative trend. It means if the climate condition as well as other factors at this moment of study still remain the same, the Dam may completely dry up. However, this hypothesis comes because the satellite imagery acquired for this study was collected during dry season. The Dadin Kowa and its environs need an abundant rainfall from now till 2029 to save the Dam from dry up.

\section{Discussion}

Satellite remote sensing has proven as a potential tool to solving hydrological monitoring and also in water resources management (Alsdorf, et al, 2007; Calmant et al, 2008). Satellite altimetry is now a good technique for monitoring large rivers, dam and reservoir, providing data for over decade (Cretaux \& Birkett, 2006). Water level data from satellite altimetry have been combined with in situ measurements to estimate water storage in lakes and reservoirs, with successful applications in different parts of the world. The water volume variation of Dadin Kowa reservoir was estimated using a relation 
developed between water level from Upper Benue River Basin Development Authority and LANDSAT data using Normalized Difference Water Index (NDWI) (Zhang et al, .2006). An alternative method to overcome such constraints is the use of the sub-pixel based approach. In this study both the per-pixel and sub-pixel approaches have been performed to extract the water spread area of the reservoir using medium resolution multi-spectral image data and the results were validated using Normalized Difference Water Index (NDWI). The result shows that from 1987 to 2000 the water level increased and decreased from 2000 to 2015 due to the climate change condition and the high rate consummation of water due to population growth of the area. The forecasting of Dadin Kowa Reservoir revealed that the water may dry off 2029 if the present climate condition and population demand remain the same or worse with the knowledge and experiences acquired in the course of this project, the following are recommended.

a) More research should be encouraged in order to determine the rate at which this reservoir is used in relation to the corresponding growth in population, temperature and evaporation changes.

b) Emphasis should be given to pre-flooding reaction instead of post flooding reaction so destruction of lives, plant and properties and can be averted.

c) They should be Assessment of climate change with emphasis in the economic consequences and integrating water and energy, water and health and water and food production.

\section{References}

Abdullaev, I.,De Fraiture, C.,Giordano, M.,Yakubov, M. \& Rasulov, A. (2009). Agricultural water use and trade in Uzbekistan, Situation and potential impacts of market liberalization. Water Resources Development 25(1): 47-63.

Alsdorf, D.,Rodriguez, E. \& Lettenmaier, D. (2007). Measuring surface water from space. Rev. Geophys, 45.

Balcik, FB. \& Göksel, C. (2012). Determination of magnitude and direction of land use/land cover changes in Terkos Water Basin, Istanbul, Intl Archives of the Photogrammetry, Remote Sensing and Spatial Information Sciences, 39, B7.

Baup, F., Frappart, F., Maubant, J. (2014). Combining high-resolution satellite images and altimetry to estimate the volume of small lakes. Hydrol. Earth Syst. Sci. 18, 2007-2020.

Birkett, C. (1995). The contribution of topex/poseidon to the global monitoring of climatically sensitive lakes. J. Geophys. Res.Oceans, 100, 25179-25204.

Burak, SZ., Doğan, E., Yücel, ZY. \& Gazioğlu, C. (2002). Havza Yönetiminde Temel İlkeler ve İstanbul Örneği (Basic Principles in Watershed Management and Istanbul Case), Türkiye Kiyl Alanlarl Milli Komitesi, KAY, 02, 335-345.
Calmant, S.,Seyler, F. \& Cretaux, J. (2008). Monitoring continental surface waters by satellite altimetry. Surv. Geophys. 29, 247-269.

Calvet, J.C.,Wigneron, J.-P.,Walker, J.,Karbou, F.,Chanzy, A. \& Albergel, C. (2011). Sensitivity of passive microwave observations to soil moisture and vegetation water content: L-band to w-band. IEEE Trans. Geosci. Remote Sens. 49, 1190-1199.

Chen, Y.,Xu, Y. \& Yin, Y. (2009). Impacts of landuse change scenarios on storm-runoff generation in Xitiaoxi basin, China. Quaternary Int. 208, (1-2) $121-128$.

Cihlar, J.,Beaubien, J.,Latifovic, R. \& Simard, G. (2005). Land cover of Canada version CD-ROM. Natural Resources Canada, Ottawa.

Congalton R. \& Green, K. (2009) Assessing the accuracy of remotely sensed data: Principles and practices, $2^{\text {nd }}$ edn. Taylor \& Francis, Baco Raton

Crétaux, F. \& Birkett, C. (2006). Lake studies from satellite radar altimetry. C. R. Geosci. 338, 10981112.

Crétaux, F.,Jelinski, W.,Calmant, S.,Kouraev, A., Vuglinski, V.,Bergé-Nguyen, M.,Gennero, C., Nino, F.,Del Rio, A. \& Cazenave, A. (2011). Sols: A lake database to monitor in the near real time water level and storage variations from remote sensing data. $A d v$. Space Res. 47, 1497-1507.

Daily, G. (1997). Nature's Services: Societal Dependence on Natural Ecosystems., Island Press: Washington, DC, USA, 329.

Desmet, P. \& Govers, G. (1996). A GIS procedure for automatically calculating the USLE LS factor on topographically complex landscape units. J. Soil Water Conserv. 51, 427-433.

Duan, Z. \& Bastiaanssen, W. (2013). Estimating water volume variations in lakes and reservoirs from four operational satellite altimetry databases and satellite imagery data. Remote Sens. Environ. 134, 403-416.

Duan, Z. \& Bastiaanssen, W. (2013). Estimating water volume variations in lakes and reservoirs from four operational satellite altimetry databases and satellite imagery data. Remote Sens. Environ. 134, 403-416.

Dukhovny, A. (2003). The Aral Sea Basin - Rumors, realities, prospects. Irrigation and Drainange. 52: 109120.

FAO (2007). http://www.fao.org.

Frappart, F., Calmant, S., Cauhopé, M., Seyler, F. \& Cazenave, A. (2006). Preliminary results of ENVISAT RA-2-derived water levels validation over the Amazon basin. Remote Sens. Environ. 100, 252264.

Frappart, F., Papa, F., Güntner, A., Werth, S., Da Silva, S., Tomasella, J., Seyler, F., Prigent, C., Rossow, B. \& Calmant, S. (2011). Satellite-based estimates of groundwater storage variations in large drainage basins with extensive floodplains. Remote Sens. Environ. 115, 1588-1594.

Frappart, F., Seyler, F., Martinez, M., Leon, G. \& Cazenave, A. (2005). Floodplain water storage in the Negro river basin estimated from microwaveremote sensing of inundation area and water levels. Remote Sens. Environ. 99, 387-399. 
Gazioğlu, C., Yücel, ZY. \& Doğan, HE. (1998). Uydu Verileriyle İstanbul Boğazı ve Yakın Çevresindeki İçme Suyu Havzalarına Genel Bir Bakış (An Overview of the Drinking Water Basins in the Bosphorus and the Surrounding Area with Satellite Data), Büyükşehirlerde Atıksu Yönetimi ve Deniz Kirlenmesi Kontrolü Sempozyumu

Göksel, Ç. (1998). Monitoring of a water basin area in Istanbul using remote sensing data, Water Science and Technology 38 (11), 209-216.

Göksel, Ç. Mercan, DE., Kapdaşılı, S.,Bektaş, F. \& Şeker, DZ. (2004). Definition of sensitive areas in a lakeshore by using remote sensing and GIS, Fresenius Environmental Bulletin 13(9), 860-864.

Heaven, S., Koloskov, B., Lock, C. \& Tanton, W. (2002). Water resources management in the Aral Basin: a river basin management model for the Syr Darya. Irrigation and Drainange. 51(2), 109-118.

$\mathrm{Hu}$, Z., Gong, H. \& Zhu, L. (2007) Fast Flooding Information Extraction in Emergency Response of Flood Disaster. Proceedings of the ISPRS Workshop on Updating Geo-Spatial Databases with Imagery and the 5th ISPRS Workshop onDMGISs, Urumchi, 28-29 August 2007, 173-177.

Hundecha, Y. \& Bardossy. A. (2004). Modeling of the effect of land use changes on the runoff generation of a river basin through parameter regionalization of a watershed model, J. Hydrol. 292, 281-295.

Iclei, (2012). Sea Level Rise Adaptation Strategy for San Diego Bay. 133, ICLEI-Local Governments for Sustainability USA, San Diego, CA.

Jawak, D., Kulkarni, K. \& Luis, J. (2015). A review on extraction of lakes from remotely sensed optical satellite data with a special focus on cryospheric lakes. Adv. Remote Sens. 4, 196213.

Jensen, R. (2009). Remote Sensing of the Environment: An Earth Resource Perspective 2/e.,Pearson Education: Delhi, India, 15-17.

Kaya, H., Yücel, ZY. \& Gazioğlu, C. (2004). Terkos Gölü'nün Sürdürülebilir Kullanımında CBS ve Uzaktan Algilama Teknolojileri (GIS and Remote Sensing Technologies for the Sustainable Use of Terkos Lake) Türkiye' nin Kıyı ve Deniz Alanları $V$. Ulusal Konferansl, 768-776.

Kaya, Ş., Şeker, DZ. \& Tanık, A. (2014). Temporal Impact of Urbanization on the Protection Zones of Two Drinking Water Reservoirs in Istanbul, Fresenius Environmental Bulletin 23 (12), 29842989.

Kazbekov, J., Rakhmatullaev, S., Huneau, F. \& Coustumer, P. (2007). Types \& Hydrogeologic Features of surface and groundwater interactions in Uzbekistan. 35th International Association of Hydrogeologists Congress, Lisbon, Portugal, 1721 September 2007. Conference Proceedings.

McFeeters, K. (1996). The use of the normalized difference water index (NDWI) in the delineation of open water features. Int. J. Remote Sens. 17, 14251432.

Medina, E., Gomez-Enri, J., Alonso, J. \& Villares, P. (2008). Water level fluctuations derived from ENVISAT Radar Altimeter (RA-2) and in-situ measurements in a subtropical waterbody: Lake
Izabal (Guatemala). Remote Sens. Environ. 112 3604-3617.

Micklin, H. \& Kluwer. (2004). The Aral Sea crisis. In: Dying and dead Seas-Climatic versus. Anthropic causes, Academic Publishers, Netherlands.,49-76.

NEMA (2012). http://nema.gov.ng/south-south-lost-n251 trn-to-floods-in-2012-says-nema/

O'Hara, L. (2000). Lessons from the past: water management in Central Asia. Water Policy 2: 365384.

Osgouei, PE. \& Kaya, Ş. (2017). Analysis of land cover/use changes using LANDSAT 5 TM data and indices, Environmental Monitoring \& Assessment 189 (4), 136.

Phan, H., Lindenbergh, R. \& Menenti, M. (2012). ICESat derived elevation changes of Tibetan lakes between 2003 and 2009. Int. J. Appl. Earth Obs. Geoinf. 17, 12-22.

Rakhmatullaev, S. (2006). Geoinformation systems for estimation of reservoir volume Capacities due to sedimentation. Final Proc. IV Conf. Specialis President Foundation ISTEDOD, November 2425 , 40-51.

Ramillien, G., Frappart, F. \& Seoane, L. (2014). Application of the regional water mass variations from grace satellite gravimetry to large-scale water management in Africa. Remote Sens. 6, 7379-7405.

Rokni, K., Ahmad, A., Selamat, A. \& Hazini, S. (2014). Water feature extraction and change detection using multitemporal LANDSAT imagery. Remote Sens. 6, 4173-4189.

Sharma, O.,Mioc, D. \& Anton, F. (2007) Feature Extraction and Simplification from Colour Images Based on Colour Image Segmentation and Skeletonization Using the Quad-Edge Data Structure. Proceedings of the International Conference in Central Europe on Computer Graphics, Visualization and Computer Vision, Plzen, 29 January-1 February 2007, 225-232.

Singh, A., Seitz, F. \& Schwatke, C. (2012). Inter annual water storage changes in the Aral Sea from multimission satellite altimetry, optical remote sensing, and GRACE satellite gravimetry. Remote Sens. Environ. 123, 187-195.

Snyder, F. (1938). Synthetic Unit Graphs. Trans. Am. Geophys. Union 19 447-454.

Sun, F., Sun, W., Chen, J. \& Gong, P. (2012). Comparison and improvement of methods for identifying waterbodies in remotely sensed imagery. Int. J. Remote Sens. 33, 6854-6875.

Timawus, M. (2010). Jonathan Needs More Than Good Luck. Daily Trust. 05-23.

Tourian, M., Elmi, O., Chen, Q., Devaraju, B., Roohi, S. \& Sneeuw, N. (2015). A spaceborne multisensor approach to monitor the desiccation of Lake Urmia in Iran. Remote Sens. Environ. 156, 349-360.

UBRB (Upper Benue River Basin). (2015). Rain fall data report in the northeast Nigeria.

UNDP (2007). Water, critical resource for Uzbekistan's future. UNDP Program, Tashkent, Uzbekistan, 121p.

USACE (2008). HEC-HMS Hydrologic Modeling System User's Manual. Hydrologic Engineering Center, Davis, CA. 
Vivoni, R. (2007). Variation of hydro meteorological conditions along a topographic transect in north western Mexico during the North American monsoon. J. Clim. 20 1792-1809.

Volpi, M.,Petropoulos, P. \& Kanevski, M. (2013). Flooding extent cartography with LANDSAT TM imagery and regularized kernel fisher's discriminant analysis. Comput. Geosci. 57, 24-31.

Wang, X.W.,Gong, P, Zhao, Y, Xu, Y.,Cheng, X.,Niu, G.,Luo, C.,Huang, B.,Sun, D. \& Li, W. (2013) Water-level changes in China's Large Lakes determined from ICESat/GLASdata. Remote Sens. Environ. 132, 134-144.

Wijesekara, N.,Gupta, A.,Valeo, C.,Hasbani Jg, Y.,Delaney, P;. \& Marceau, J.,(2012) Assessing the impact of future land-use changes on hydrological processes in the Elbow River watershed in southern Alberta, Canada. J. Hydrol. 412-413 220-232.

World Bank. (2003). Irrigation in Central Asia: Social, economic and environmental considerations.

Yan, J. \& Qi, W. (2012). Lakes in Tibetan Plateau extraction from remote sensing and their dynamic changes. Acta Geosci. Sin. 33, 65-74.

Yang, X. (2002). Satellite monitoring of urban spatial growth in the Atlanta metropolitan area. Photogramm Eng Remote Sens 68:725-734

Yücel, ZY., Gazioğlu, C. Doğan, E. \& Kaya, H. (2002). Uzaktan Algılama ve CBS/B ile Ömerli Barajı ve Yakın Çevresinin İzlenmesi (Monitoring of Ömerli Dam and its Neighborhood with Remote Sensing and GIS) Türkiye'nin Klyı ve Deniz Alanları IV Ulusal Konferansi. 5-8.

Zhang, J.,Xu, K.,Yang, Y.,Qi, L.,Hayashi, S. \& Watanabe, M. (2006). Measuring water storage fluctuations in Lake Dongting, China, by Topex/Poseidon satellite altimetry. Environ. Monit. Assess. 2006, 115, 23-37.

Zhu,W.,Jia, S. \& Lv, A. (2014). Monitoring the fluctuation of Lake Qinghai using multi-source remote sensing data. Remote Sens. 6, 1045. 
Jesse., et al., / IJEGEO (6)1: 115-130 (2019)

APPENDIXES UPPER BENUE RIVER BASIN DEVELOPMENT AUTHORITY DADINKOWA DAM RESERVOIR MONITORING RECORD

RESERVOIR WATER LEVEL (above mean sea level (amsl))

\begin{tabular}{|c|c|c|c|c|c|c|c|c|c|c|c|c|}
\hline & & & & & & & & & & & Year & 1987 \\
\hline Day & Jan & Feb & Mar & Apr & May & Jun & Jul & Aug & Sept & Oct & Nov & Dec \\
\hline 1 & 0.00 & 0.00 & 0.00 & 215.55 & 219.87 & 0.00 & 229.32 & 233.15 & 237.97 & 239.82 & 239.95 & 239.55 \\
\hline 2 & 0.00 & 0.00 & 0.00 & 217.22 & 219.88 & 0.00 & 229.37 & 233.24 & 238.18 & 239.84 & 239.91 & 239.54 \\
\hline 3 & 0.00 & 0.00 & 0.00 & 217.93 & 219.89 & 0.00 & 229.49 & 233.34 & 238.55 & 239.89 & 239.90 & 239.53 \\
\hline 5 & 0.00 & 0.00 & 0.00 & 218.73 & 219.92 & 0.00 & 229.49 & 233.55 & 238.65 & 239.89 & 239.87 & 239.58 \\
\hline 6 & 0.00 & 0.00 & 0.00 & 218.98 & 219.93 & 0.00 & 229.56 & 233.70 & 238.78 & 239.90 & 239.86 & 239.51 \\
\hline 7 & 0.00 & 0.00 & 0.00 & 219.05 & 216.96 & 0.00 & 229.68 & 233.70 & 238.81 & 239.96 & 239.85 & 239.49 \\
\hline 11 & 0.00 & 0.00 & 0.00 & 219.27 & 220.04 & 0.00 & 230.09 & 233.95 & 239.09 & 0.00 & 239.79 & 239.45 \\
\hline 12 & 0.00 & 0.00 & 0.00 & 219.33 & 220.05 & 0.00 & 230.28 & 234.15 & 239.13 & 240.06 & 239.77 & 239.44 \\
\hline 13 & 0.00 & 0.00 & 0.00 & 219.37 & 220.08 & 0.00 & 230.58 & 234.61 & 239.27 & 240.09 & 239.77 & 239.44 \\
\hline 14 & 0.00 & 0.00 & 0.00 & 219.42 & 220.09 & 0.00 & 230.78 & 234.74 & 239.33 & 240.10 & 239.76 & 239.43 \\
\hline 15 & 0.00 & 0.00 & 0.00 & 219.44 & 220.11 & 0.00 & 230.92 & 234.86 & 239.39 & 240.10 & 239.74 & 239.41 \\
\hline 16 & 0.00 & 0.00 & 0.00 & 219.48 & 220.11 & 0.00 & 231.12 & 234.97 & 239.42 & 240.12 & 239.72 & 239.41 \\
\hline 17 & 0.00 & 0.00 & 0.00 & 219.53 & 220.15 & 0.00 & 231.32 & 235.05 & 239.45 & 240.11 & 239.72 & 239.40 \\
\hline 22 & 0.00 & 0.00 & 0.00 & 219.69 & 220.23 & 0.00 & 231.88 & 235.97 & 2239.68 & 240.06 & 239.64 & 239.36 \\
\hline 23 & 0.00 & 0.00 & 0.00 & 219.72 & 220.23 & 0.00 & 232.03 & 236.18 & 239.55 & 240.05 & 239.63 & 239.39 \\
\hline 24 & 0.00 & 0.00 & 0.00 & 219.74 & 220.26 & 0.00 & 232.25 & 236.34 & 239.71 & 240.04 & 239.62 & 239.34 \\
\hline 25 & 0.00 & 0.00 & 0.00 & 219.76 & 220.25 & 0.00 & 232.43 & 236.51 & 239.74 & 240.03 & 239.61 & 239.33 \\
\hline 26 & 0.00 & 0.00 & 0.00 & 219.78 & 220.28 & 0.00 & 232.59 & 236.74 & 0.00 & 240.02 & 239.59 & 239.33 \\
\hline 27 & 0.00 & 0.00 & 0.00 & 219.81 & 220.29 & 0.00 & 232.71 & 236.93 & 239.80 & 240.00 & 239.59 & 239.32 \\
\hline 28 & 0.00 & 0.00 & 0.00 & 219.82 & 220.33 & 0.00 & 232.82 & 237.14 & 239.80 & 239.99 & 239.58 & 239.31 \\
\hline 29 & 0.00 & 0.00 & 0.00 & 219.83. & 220.32 & 0.00 & 232.90 & 237.33 & 239.81 & 239.98 & 239.57 & 239.25 \\
\hline 30 & 0.00 & & 0.00 & 219.85 & 0.00 & 0.00 & 232.98 & 237.56 & 239.82 & 239.95 & 239.56 & 239.31 \\
\hline 31 & 0.00 & & 0.00 & & 0.00 & 0.00 & 233.06 & 237.81 & & 239.94 & & 239.30 \\
\hline Mean & \#Div/0! & \#Div/0! & \#Div/0! & 219.19 & 220.10 & & 231.07 & 235.12 & 239.22 & 240.01 & 239.74 & 239.41 \\
\hline $\begin{array}{l}\text { Max } \\
\text { Month }\end{array}$ & 0.00 & 0.00 & 0.00 & 219.85 & 220.33 & 0.00 & 233.06 & 237.81 & 239.82 & 240.12 & 239.95 & 239.58 \\
\hline
\end{tabular}


Jesse., et al., / IJEGEO (6)1: 115-130 (2019)

APPENDIXES UPPER BENUE RIVER BASIN DEVELOPMENT AUTHORITY DADINKOWA DAM RESERVOIR MONITORING RECORD RESERVOIR

WATER LEVEL (above mean sea level (amsl))

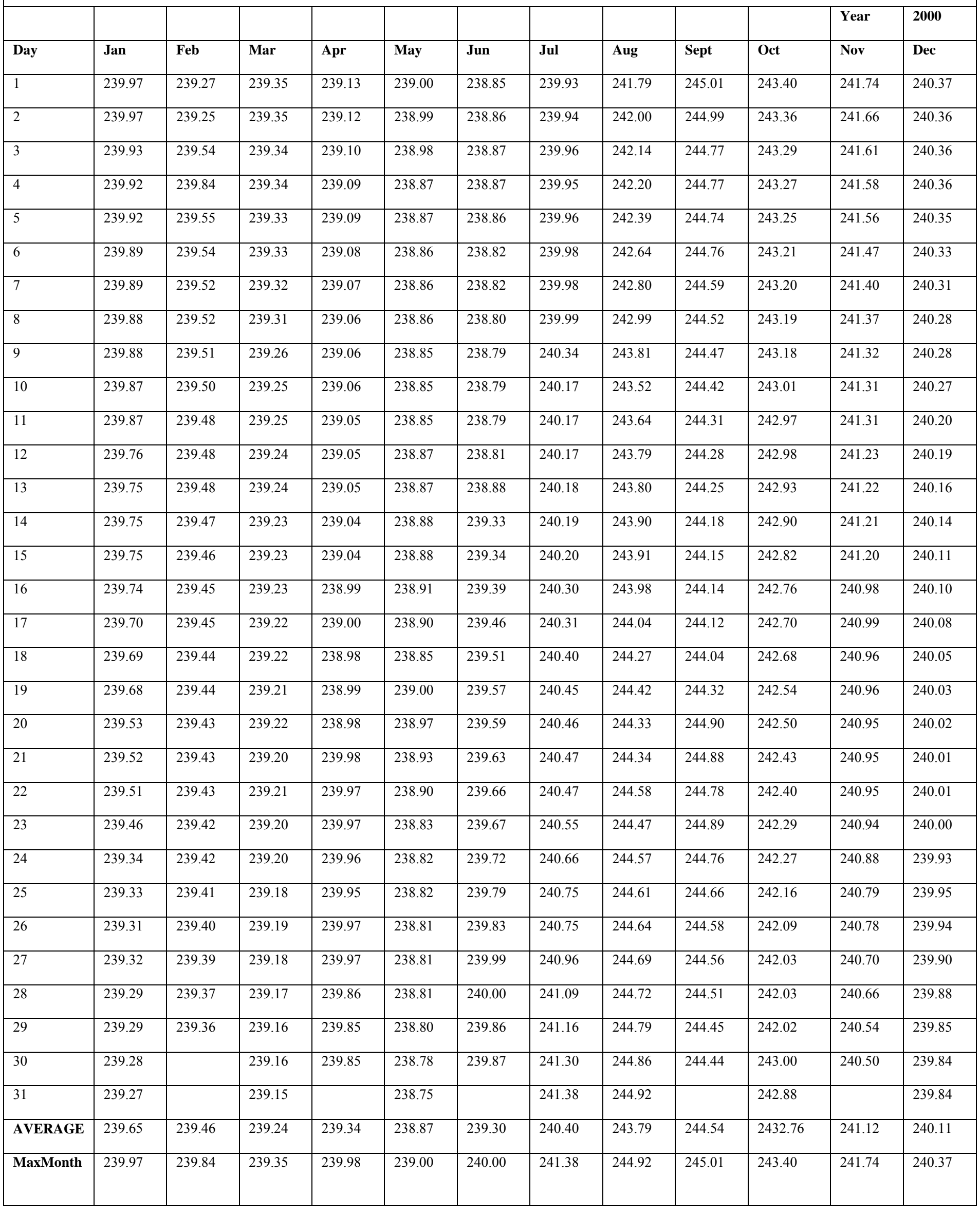


APPENDIXESUPPER BENUE RIVER BASIN DEVELOPMENT AUTHORITY DADINKOWA DAM RESERVOIR MONITORING RECORD RESERVOIR

WATER LEVEL (above mean sea level (amsl))

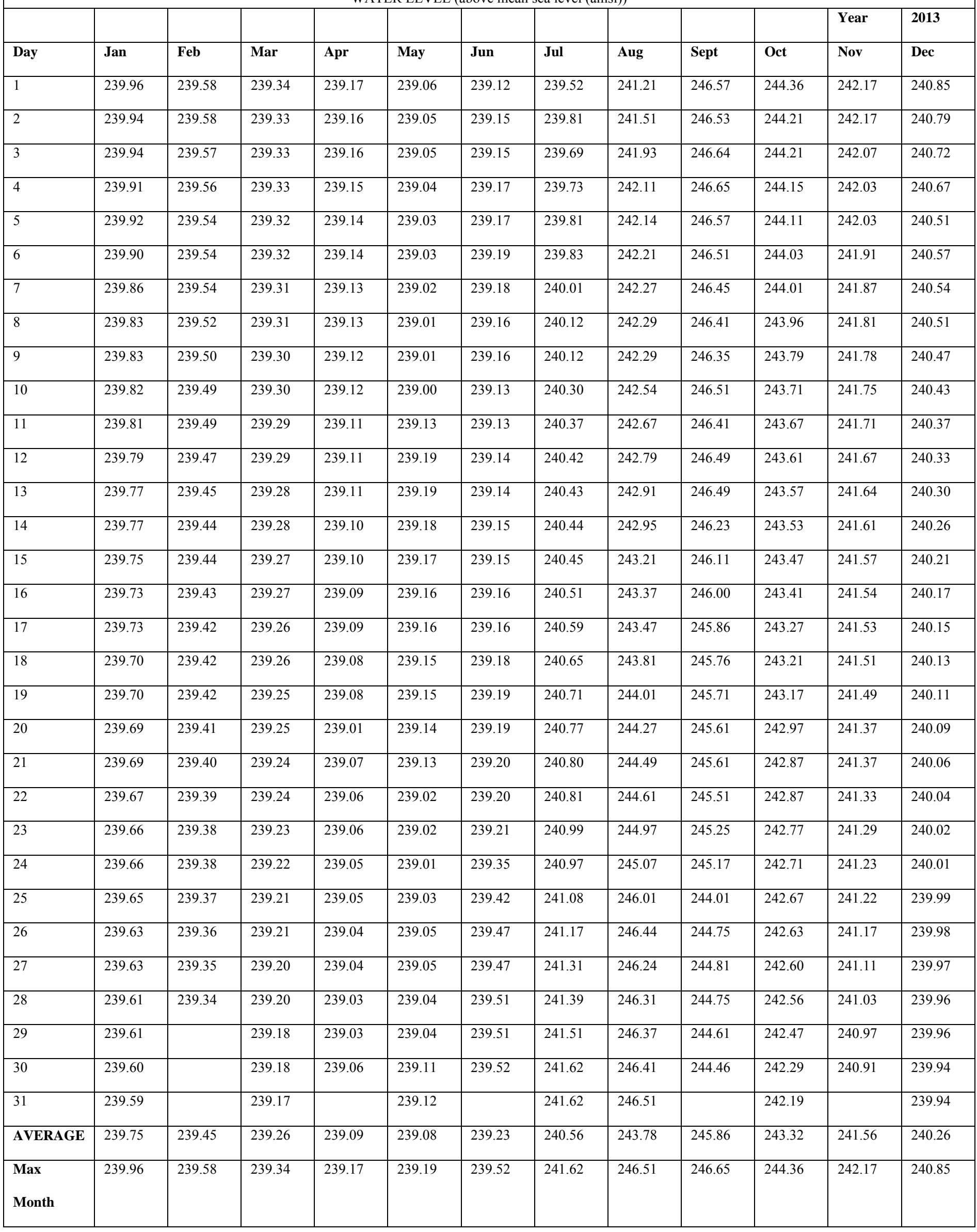




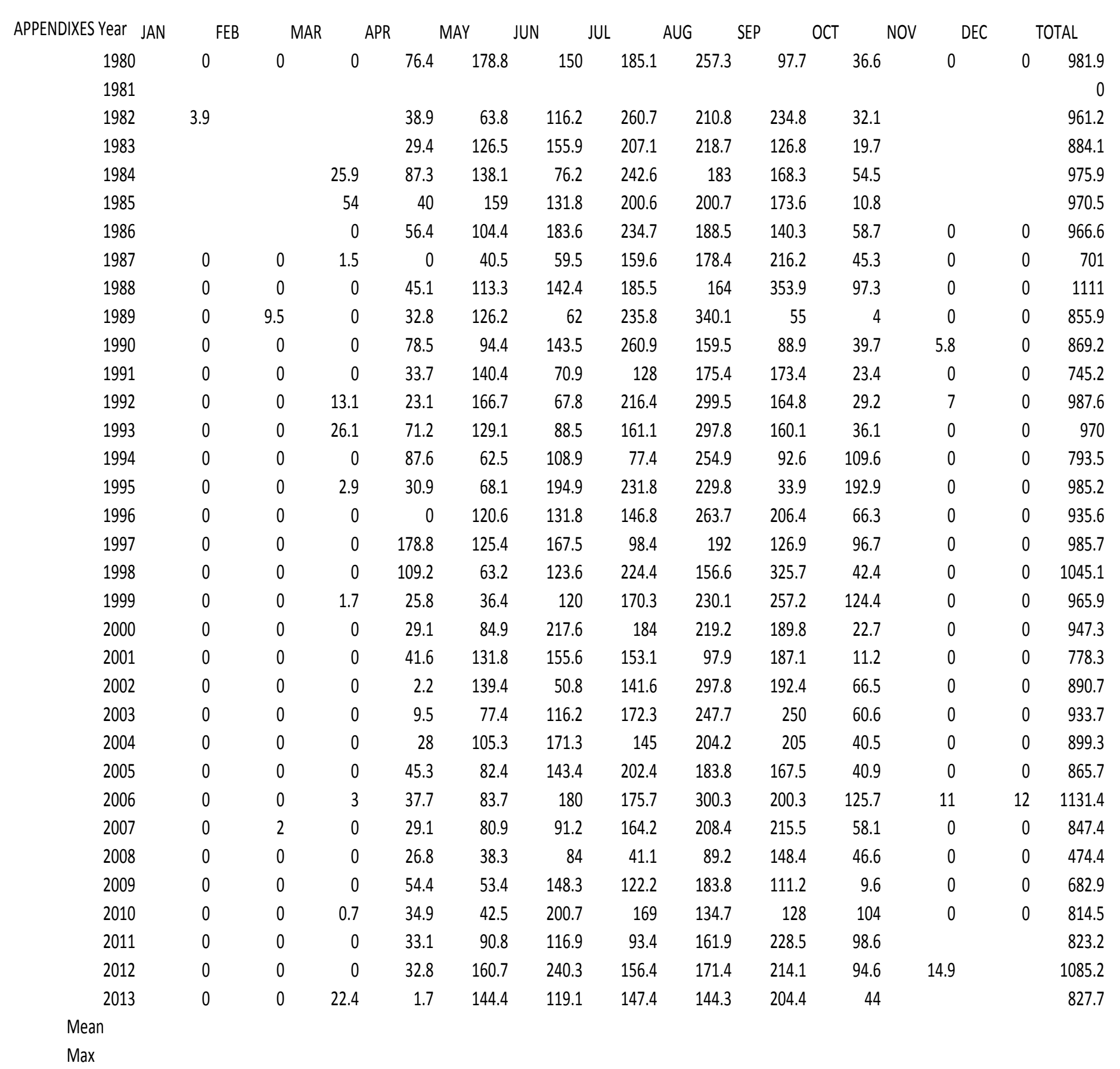

Rainfall data of Dadin Kowa (Source: UBRB 2015) 